OCTOBER 2020, VOLUME 8, ISSUE 4, 1 - 23

E-ISSN NO: $2289-4489$

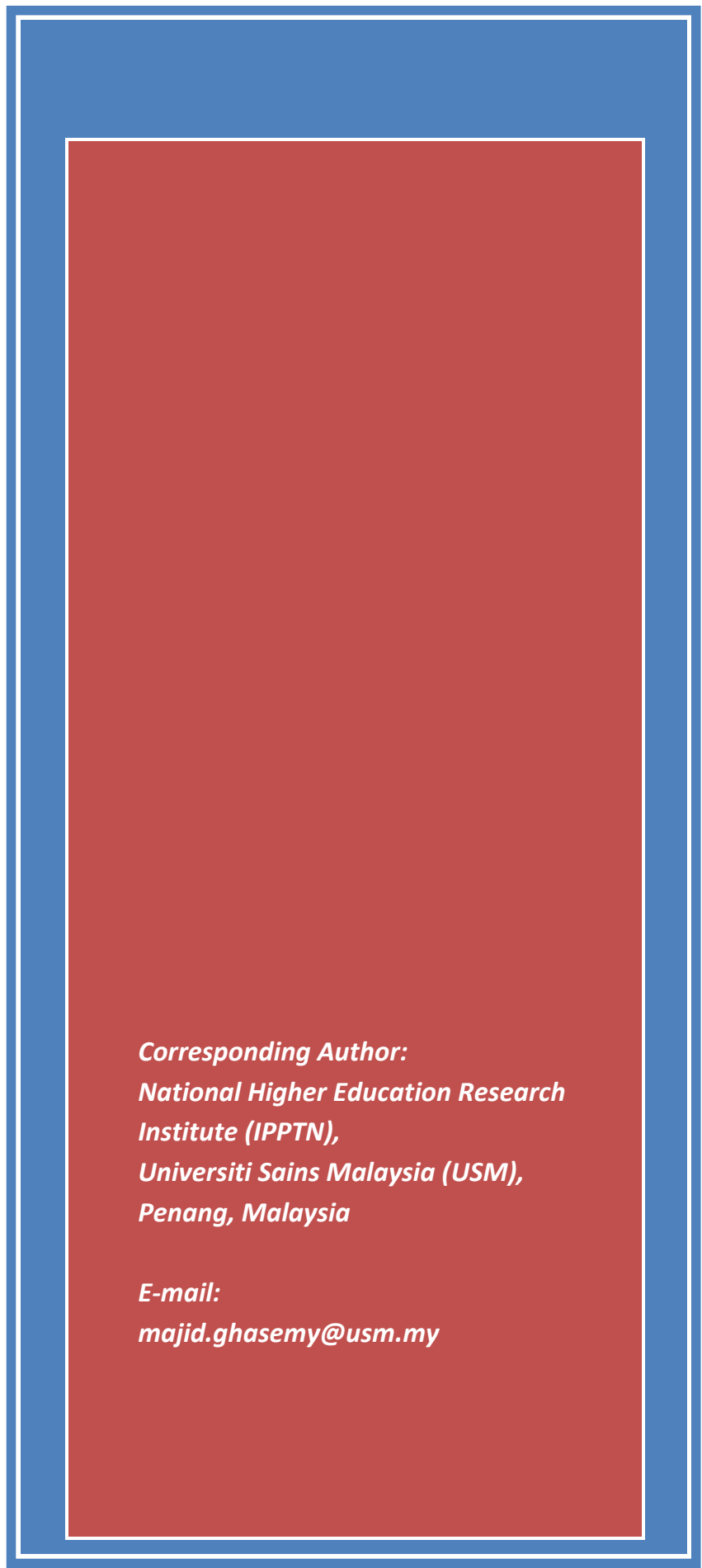

\title{
ACADEMIC CHANGE-ORIENTED LEADERSHIP CAPABILITY: THE APPLICATION OF SATORRA-BENTLER ROBUST METHOD IN A SCALE VALIDATION STUDY
}

Majid Ghasemy (PhD)*, Ahmad Firdaus Ahmad Shabudin, Noraini Mohamad Yusof \& Ooi Poh Ling

\begin{abstract}
This research aims at validating a previously developed 5-factor model of changeoriented leadership capability scale in academic settings. Data were collected from Malaysian academic leaders in 25 public and private universities through an online survey distribution platform. The result of data screening procedure highlighted the existence of one outlying case, which was removed from the dataset. In addition, the assumption of multivariate normality was not met. Hence, to run a confirmatory analysis to test the factorial validity of the proposed scale, we applied the robust Maximum-Likelihood (ML) methodology in EQS 6.4 software package to correct the chi-square statistic and generate robust standard errors. The outcome of the analysis shed light on the fact that the change-oriented capability scale developed in academic settings was a 4-factor model. In addition, the fit indices and standard errors generated through conventional $\mathrm{ML}$ estimator and the robust method were compared to provide more insights regarding the undue influence of the multivariate non-normal data on fit indices and standard errors. The implications of the findings with respect to the practice, theory, and methodology were discussed as well.
\end{abstract}

Keywords: Change-Oriented Leadership, Leadership and Management, Malaysian Higher Education, Multivariate Methods, Structural Equation Modelling, Factorial Validity 


\section{MALAYSIAN ONLINE JOURNAL OF EDUCATIONAL MANAGEMENT (MOJEM)}

\section{INTRODUCTION}

In today Volatile, Uncertain, Complex and Ambiguous (VUCA) global and local landscape, Higher Education Institutions (HEls) are experiencing significant transformations in their policies, governance, management, human resources, services (teaching and learning, research and development, community engagement), and so on. For the successful adaptation of Higher Education $(\mathrm{HE})$ in various turbulent and disruptive waves, there is a need for diligent and skillful academic leaders. Given the existence of the global and national challenges and the fact that HE ecosystem is undergoing significant transformations, it is crucial to identify the main issues in HE sector namely priorities, values, challenges, and solutions from the perspectives of academic leaders (Ghasemy, Sufean, Megat Ahmad Kamaluddin, et al., 2018). Black (2015) proposed 15 main challenges for HE leadership, of which a few include bureaucracy, which leads to inefficiency and ineffectiveness, the presence of multi-role academic leaders, the need to adapt to new circumstances, globalization and internationalization, and university governance. Thus, the most pertinent leadership style needs to be adopted by academic leaders to promote values, shatter the barriers, and lead universities commendably.

Stensaker et al. (2014) highlight leadership, decision-making procedures, communication, and evaluation are keys to ensure successful HEls in making strategic choices while dealing with external pressures and a changing public policy environment (Croucher \& Lacy, 2020). Hence, the relevancy and appropriateness of leadership behaviors and practices must be examined in HE domain. This scenario calls for $\mathrm{HE}$ to take a leadership role in implementing major transformations as well as fostering the future leaders who would be prepared to manage these challenges magnificently.

Essentially, making remarkable transformations in $\mathrm{HE}$ sector has been tied with leadership, and leadership has been viewed as the main element in the conceptual framework of sustainability in HEls (Scott, Tilbury, Sharp, \& Deane, 2012). This implies the considerable role of academic leaders during the period of development and growth and highlights the significance of practicing change-oriented leadership capabilities (Arvonen, 2008; Yukl, 2012) in universities. Change-oriented leadership offers a wide range of behaviors compared with transformational and charismatic leadership styles (Yukl, 2004), and we believe, it seems to be the leadership of choice in overcoming the complex sustainability challenges namely, social, cultural, economic, and environmental challenges in university settings (Scott et al., 2012). It is worth noting that Malm (2008) has identified a few strategies to conquer the future challenges that universities would face. Among these strategies, visioning and strategizing, communication, and an appropriate decision-making process are directly consonant with change-oriented leadership characteristics identified in the studies theorizing this style of leadership (Arvonen, 2008; Ekvall, 1991; Ekvall \& Arvonen, 1991; Yukl, 2004, 2012). Moreover, the recent study by King Jr (2017) offers insights about the importance of change-oriented leadership style in academic settings. The study mentioned the potential of change-oriented leadersip to engage staff more directly in the strategic changes required for organizational survival and success, thereby bringing about a higher level of the individual, organizational, and social change.

Despite a growing interest in practicing change-oriented behaviors as a leadership strategy to boost the change processes and its importance in HE leadership literature (Ghasemy, Sufean, Ahmad Zabidi, Mohd Jamil, \& Ghavifekr, 2018; Ghasemy, Sufean, \& Megat Ahmad Kamaluddin, 2017; Ghasemy, Sufean, Megat Ahmad Kamaluddin, Ahmad Zabidi, \& Mohd Jamil, 2017), there is no relevant and verified scale to operationalize change-oriented leadership capabilities in HE settings. In relation to this, it is pertinent to develop and validate the scale of change-oriented leadership among leaders in the context of HEIs. 


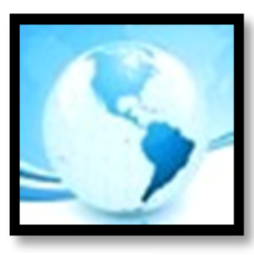

\section{RESEARCH OBJECTIVES}

With this brief introduction, to provide an appropriate instrument to measure change-oriented leadership capability, especially in the context of the institutions of higher learning, as well as to expand the borders of the knowledge in terms of this new dimension of leadership capabilities, the current study aims at validating the developed 5-factor model of change-oriented leadership capability (Ghasemy, Sufean, \& Megat Ahmad Kamaluddin, 2015) in academic settings. It is remarkable to highlight that through the current study, a confirmatory analysis is carried out to test the hypothesis that change-oriented leadership capability is a 5-factor model.

Notably, the validation of the change-oriented leadership scale in this study should have several potential implications. As an example, while change-oriented capability may be acceptedly measured using the validated scale, researchers can focus on the antecedents and consequences of such capabilities in the current dynamic HE ecosystem. In a broader context (e.g., national context), the practice of changeoriented leadership capability is crucial to achieve the aspired goals in Malaysian Higher Education Blueprint 2015-2025 with respect to developing and fostering academic leaders who are capable of implementing change programs effectively and have the right mindsets, behaviors, skills, and visions to drive the transformation of Malaysian HEls.

\section{LITERATURE REVIEW AND THEORETICAL UNDERPINNING}

Leaders have been regarded as change agents in organizations during the period of transformation and development (Avolio \& Gibbons, 1988). As a result, leadership has been the most crucial factor leading to successful reform (Kotter, 1999). In fact, Kotter (1999) highlights the effective internal change processes which are capable of coping with external change forces and are created within the organizations with high-performance capabilities and strong leadership. These can lead to adaptation to change in such a way that will make the enterprise even stronger to meet tomorrow's needs. For this reason, identifying effective leadership capabilities has always been essential.

A review of more than 40 years of leadership literature shows that identifying leadership capabilities and behaviours has been a core target in many studies until recently, leading to pinpoint two categories of leadership behaviours focusing on the task and human elements. As reported by Arvonen (2008), these two dimensions have differently been written off as democratic and authoritarian (Lewin, 1950), consideration and initiation of structure (Bass, 1960; Fleishman \& Harris, 1962), employee-centered and job-centered supervision (Likert, 1961), concern for people and concern for production (Blake \& Mouton, 1985), boss-centered and subordinate-centered behaviours (Tannenbaum \& Schmidt, 1973), task-oriented and relationship-oriented (Hersey \& Blanchard, 1988), and lastly, directive and participative leadership (Bass \& Stogdill, 1990).

Nevertheless, in the 1990s, change-oriented or change-centered leadership, as a new dimension of leadership capability with a wide range of capabilities, was emerged through two factorial analysis studies conducted by Ekvall and Arvonen (1991) and Yukl (1999) and later was supported empirically (Arvonen, 2008; Ekvall, 1991; Yukl, Gordon, \& Taber, 2002) as well. The results of Ekvall and Arvonen (1991) have been displayed in Figure 1. 


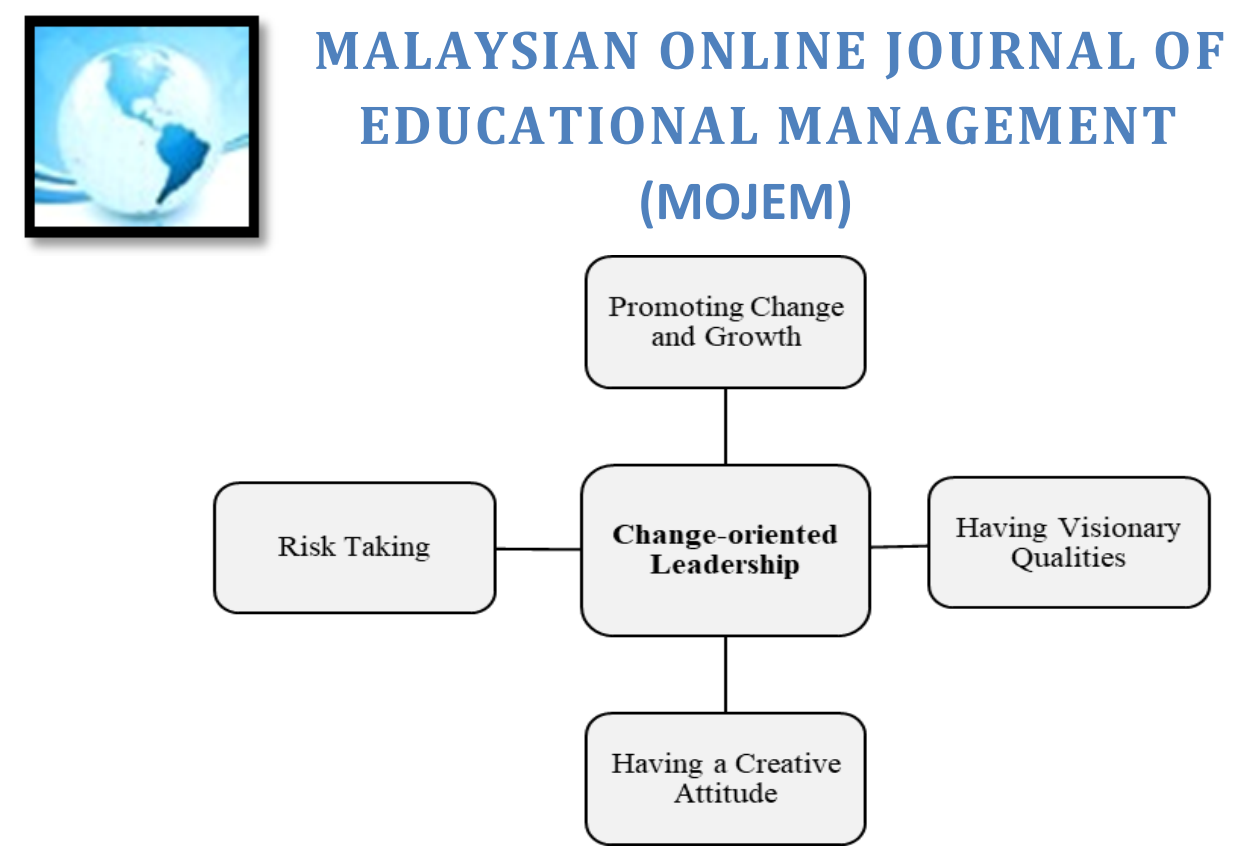

Figure 1. Change-oriented behaviours as proposed by Ekvall and Arvonen (1991)

Although this new dimension, along with the task-oriented and human-oriented capabilities, was emphasized and addressed in two more recent studies (Arvonen, 2008; Yukl, 2004), in the latest study focusing on conceptualizing leadership behaviours (Yukl, 2012), a set of four categories namely, task-oriented, human-oriented, changeoriented and external behaviours were proposed. More specifically, Yukl (2012) debated that four constructs namely, advocating change, envisioning change, encouraging innovation, and facilitating collective learning form change-oriented leadership capability (Figure 2).

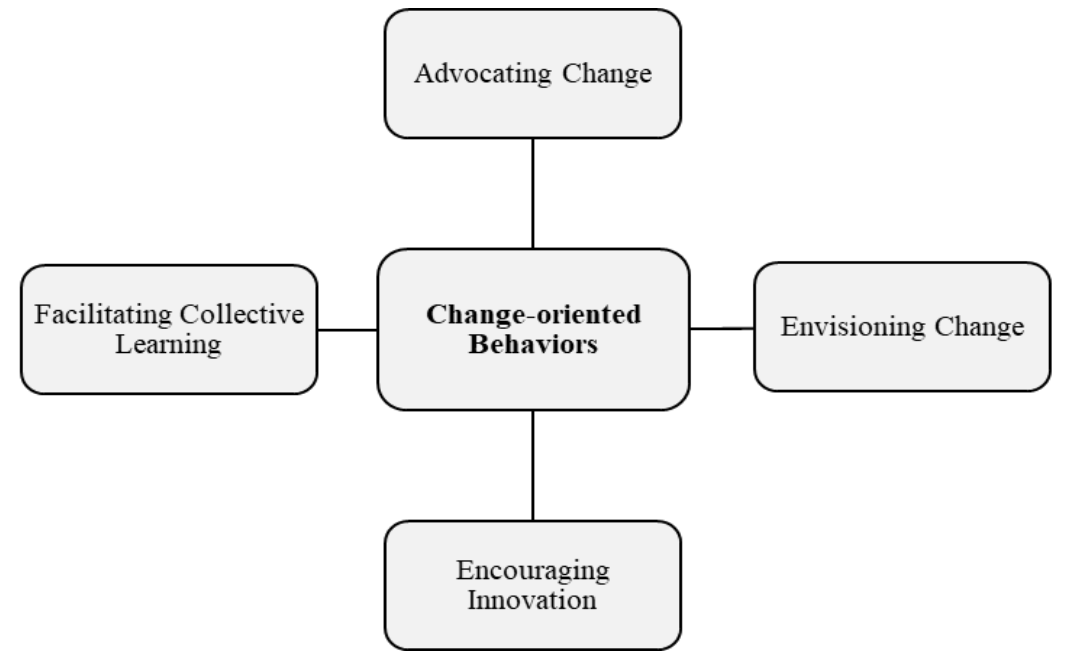

Figure 2. Change-oriented behaviours as proposed by Yukl (2012)

Despite this last finding in terms of proposing a taxonomy for leadership capabilities with four dimensions, Borgmann, Rowold, and Bormann (2016) conducted a study intending to provide empirical support for the taxonomy of leadership capabilities with three categories proposed by Yukl et al. (2002). Through this research attempt, secondary data were collected, and the results of the analysis provided support for the three-dimensional taxonomy proposed by Yukl et al. (2002). Additionally, their study revealed that change-oriented leadership capability, in comparison with the two leadership behaviour dimensions, was a better predictor of the followers' job satisfaction. 


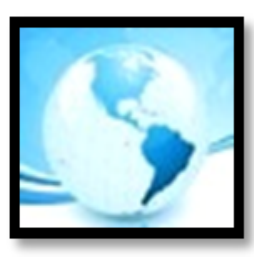

\section{MALAYSIAN ONLINE JOURNAL OF EDUCATIONAL MANAGEMENT (MOJEM)}

It is noteworthy that the review of the recent change-oriented leadership literature led to identify limited pieces of evidence in terms of examination, application, and practice of this leadership style in different sectors as well (Ghasemy, 2017; Ghasemy et al., 2015; Ghasemy, Sufean, \& Megat Ahmad Kamaluddin, 2017; Ghasemy, Sufean, Megat Ahmad Kamaluddin, et al., 2017; Gil, Rico, Alcover, \& Barrasa, 2005; Golm, 2009; Holloway, 2013; Khalili, 2017; King Jr, 2017; Marinova, Peng, Lorinkova, Van Dyne, \& Chiaburu, 2015; Ortega, Van den Bossche, SánchezManzanares, Rico, \& Gil, 2013; Sirén, Patel, \& Wincent, 2016; Vardaman, 2013). For instance, Ekvall and Ryhammar (1998) studied the mediating effect of climate on the relationship between leadership style and creativity. They analysed three leadership dimensions including change-, human- and production-oriented leadership styles in the context HE. Also, Hansson and Andersen (2007) studied the relationship between leadership style, decision-making style, and motivation profile among school principals in Sweden, which led to the conclusion that $49 \%$ of the principals practicing change-oriented behaviours. Furthermore, Sellgren, Ekvall, and Tomson (2008) conducted another study in a large university hospital to examine the relationship between managers' leadership behaviours (production-oriented, employee-oriented, and change-oriented leadership styles), job satisfaction and a creative work climate.

While the review of the literature shows that new models illustrating the effect of change-oriented leadership on other variables have been developed through international large-scale quantitative research (e.g., Gil et al. (2005) and Ortega et al. (2013)), only limited number of studies were identified which had applied advanced secondgeneration analytic methods (Hair, Hult, Ringle, \& Sarstedt, 2017) to analyse the data. This was considered as a clear sign of methodological and analytical flaws in the literature of change-oriented leadership capability. Moreover, from a business industry perspective, although HEls in any economy play major roles in terms of maintaining sustainability and enhancement of the societies (Mourad, 2013) and are regarded as mature organizations facing a lot of challenges and reforms (Black, 2015; Fullan \& Scott, 2009; Ghasemy, Sufean, \& Megat Ahmad Kamaluddin, 2018), the literature still lacks of the studies focusing on change-oriented leadership style in this context.

\section{METHOD}

\section{Research Design and Analytic Procedure}

This quantitative research work is a survey study underpinned by the assumptions of the post-positivism worldview (Creswell, 2012). Given its confirmatory approach and due to the need for the global fit indices (Hair et al., 2017), the Covariance-Based Structural Equation Modeling (CB-SEM) method was considered for the purpose of the primary data analysis. Notably, the researchers employed IBM SPSS Statistics 24 to screen the data with respect to identifying obvious unusual cases as well as predicting and replacing missing values. In addition, all the parameters of the hypothesized model in the study were examined in terms of their feasibility, appropriateness of standard errors, and their statistical significance using EQS 6.4 software package (Bentler, 1985, 2006). To this end, the guidelines proposed by Byrne (2006) and Bentler (2006) were followed as the principles ensuring the quality and creditability of the analytic procedures. In addition, the researchers considered the best-practice guidelines proposed by Green (2016) in terms of the proper application of the method.

\section{Measures}

To collect data, the academic change-oriented leadership capability scale developed by Ghasemy et al. (2015) was employed. This scale, developed through a rigorous Principal Component Analysis (PCA) and Velicer's MAP test (O'Connor, 2000), contains five subscales namely, Strategic Environmental Scanning (SES), Supporting Organizational Culture (SOC), Thinking Out of the Box (TOB), Having Clear Objective Focus (HCOF), and Overcoming Obstacles (OOb). It is noticeable that the scale has been successfully employed in a few previous research studies (Ghasemy, 2017; Ghasemy, Sufean, \& Megat Ahmad Kamaluddin, 2017; Ghasemy, Sufean, Megat Ahmad Kamaluddin, et al., 2017). Example for the items include "Being sensitive to the information regarding the 


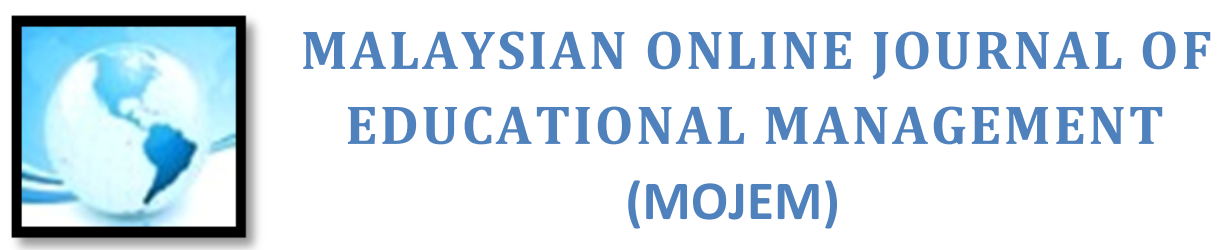

technological developments", "Creating an organizational culture that values creativity and entrepreneurial activities", "Liking and encouraging to discuss new ideas", "Avoiding taking actions that can divert attention from innovative solutions", and "Trying to remove the obstacles related to maintaining the status quo". Table 1 shows the previously reported reliability estimates of the sub-scales of the academic change-oriented leadership capability scale.

Table 1

Reliability Coefficients of the Sub-Scales of Academic Change-Oriented Leadership Capability Scale (Ghasemy Et Al., 2015)

\begin{tabular}{llll}
\hline Scale & Subscale & No. of items & Alpha at subscale level \\
\hline Change-oriented & Strategic environmental scanning (SES) & 9 & 0.924 \\
Behaviours & Supporting organizational culture (SOC) & 6 & 0.887 \\
& Thinking out of the box (TOB) & 5 & 0.867 \\
& Having clear objective focus (HCOF) & 3 & 0.768 \\
& Overcoming obstacles (OOb) & 3 & 0.739 \\
\hline
\end{tabular}

The correlations among these sub-scales, as reported by Ghasemy et al. (2015), have been displayed in Table 2 as well.

Table 2

Correlation among the Sub-Scales of Academic Change-Oriented Leadership Capability Scale

\begin{tabular}{|c|c|c|c|c|c|}
\hline Component & SES & SOC & TOB & HCOF & $\mathrm{OOb}$ \\
\hline SES & 1.000 & & & & \\
\hline SOC & .479 & 1.000 & & & \\
\hline TOB & .631 & .466 & 1.000 & & \\
\hline $\mathrm{HCOF}$ & .557 & .528 & .534 & 1.000 & \\
\hline $\mathrm{OOb}$ & .494 & .369 & .408 & .403 & 1.000 \\
\hline
\end{tabular}

\section{Participants and Sampling Procedure}

The target population of this study are Malaysian academic leaders namely, vice-chancellors, deputy vicechancellors, deans, directors, deputy deans, deputy directors, heads of departments, and professors without any formal positions in Malaysian institutions of higher learning. To collect data, the database of the email addresses of the potential respondents was created, and the instrument was administered using SurveyMonkey platform among 2786 academic leaders. In total, 399 surveys were collected (response rate $=14.32 \%$ ) of which 20 surveys were partially completed. Consequently, the researchers did not consider them as they were not appropriate for the data analysis. The demographic information of the sample $(\mathrm{N}=379)$ has been displayed in Table 3.

Table 3

Demographic Information of the Sampled Academic Leaders ( $N=379)$

\begin{tabular}{llll}
\hline Variable & Categories & Frequency & Percent \\
\hline Gender & Male & 227 & 59.9 \\
& Female & 152 & 40.1 \\
\hline Age group & Under 36 & 16 & 4.2 \\
& $36-45$ & 112 & 29.6 \\
& $46-55$ & 134 & 35.4 \\
& $56-65$ & 93 & 24.5 \\
& Over 65 & 24 & 6.3 \\
\hline
\end{tabular}




\begin{tabular}{|c|c|c|c|}
\hline \multirow{2}{*}{ Marital status } & \multicolumn{3}{|c|}{$\begin{array}{l}\text { MALAYSIAN ONLINE JOURNAL OF } \\
\text { EDUCATIONAL MANAGEMENT } \\
\text { (MOJEM) }\end{array}$} \\
\hline & Single & 45 & 11.9 \\
\hline Marital status & Married & 334 & 88.1 \\
\hline \multirow[t]{4}{*}{ Academic rank } & Professor & 169 & 44.6 \\
\hline & Associate Professor & 87 & 23.0 \\
\hline & Assistant Professor / Senior Lecturer & 97 & 25.6 \\
\hline & Other & 26 & 6.9 \\
\hline \multirow[t]{8}{*}{ Current role } & Vice-Chancellor & 2 & 0.5 \\
\hline & Deputy Vice-Chancellor & 10 & 2.6 \\
\hline & Dean & 49 & 12.9 \\
\hline & Director & 40 & 10.6 \\
\hline & Deputy Dean & 79 & 20.8 \\
\hline & Deputy Director & 16 & 4.2 \\
\hline & Head of Department & 104 & 27.4 \\
\hline & Professor with no position & 79 & 20.8 \\
\hline \multirow[t]{2}{*}{ Experience outside $\mathrm{HE}$} & Yes & 187 & 49.3 \\
\hline & No & 192 & 50.7 \\
\hline
\end{tabular}

Data screening and Common Method Bias

Missing values analysis was run to predict and replace the missing values for each sub-scale. For this purpose, Expectation-Maximization (EM) algorithm (Ho, 2013) was considered. The non-significant result of the Little's Missing Completely at Random (MCAR) test confirmed that the data were missing completely at random, indicating the appropriateness of the method applied to predict and replace missing values. Table 4 shows the chisquare statistics and their associated Degrees of Freedom (DF) as well as the significance values of Little's MCAR test.

Table 4

Results of EM Algorithm Employed to Predict and Replace Missing Values

\begin{tabular}{lll}
\hline No. & Subscale & Little's MCAR test result \\
\hline 1 & SES & Chi-Square $=87.028$, DF $=91$, Sig. $=.598$ \\
2 & SOC & Chi-Square $=35.245, D F=38$, Sig. $=.598$ \\
3 & TOB & Chi-Square $=21.025$, DF $=23$, Sig. $=.580$ \\
4 & HCOF & Chi-Square $=8.324, D F=7$, Sig. $=.305$ \\
5 & OOb & Chi-Square $=9.532$, DF $=8$, Sig. $=.299$ \\
\hline
\end{tabular}

Next, EQS 6.4 was employed to specify the 5 -factor model of academic change-oriented leadership capability scale. Upon completion of this step, ML estimator (Bentler, 2006; Byrne, 2006) was selected to estimate the parameters as well as to generate the required statistics to examine the requirements of the analysis. To this end, the outputs of EQS with regard to multivariate outliers as well as univariate and multivariate normality were focused. The existence of multivariate outliers was assessed through examining the cases with the largest contributions to the normalized multivariate kurtosis (Byrne, 2006). The procedure showed there was one outlying case within the data, which had a considerably large estimated value compared with other potential outliers. Thus, this case was considered for deletion from the dataset in the next phase of the analysis. With respect to univariate normality, as quoted by Byrne (2016), since kurtosis severely affects tests of variances and covariances (DeCarlo, 1997), the univariate kurtosis values were examined. This shed light on the fact that all of these univariate kurtosis values were less than seven, indicating no cause for concern in terms of univariate normality (West, Finch, \& Curran, 1995). Regarding the multivariate normality requirement, the normalized estimate of multivariate kurtosis (Mardia, 1970, 1974) was focused. This value (40.97) was greater than five, which was indicative of multivariate 


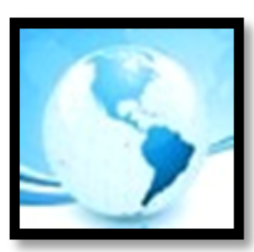

\section{MALAYSIAN ONLINE JOURNAL OF EDUCATIONAL MANAGEMENT (MOJEM)}

non-normality of the data (Bentler, 2006). Hence, while the only outlying case was removed from the dataset, the second round of SEM analysis was performed. As suggested by Byrne $(2006,2016)$, the robust estimator that generates a corrected chi-square statistic, known as Satorra-Bentler scaled chi-square or S-B $\chi^{2}$, as well as the robust standard errors (Bryant \& Satorra, 2012; Chou, Bentler, \& Satorra, 1991; Satorra \& Bentler, 1988, 1994, 2001, 2010) was considered. Notably, this correction to the Maximum Likelihood (ML) estimator has been regarded as the most straightforward strategy when the assumption of multivariate normality has not been met (Bentler, 2006; Byrne, 2006, 2016; Finney \& DiStefano, 2006). Moreover, the corrected chi-square statistic has been shown to be the most reliable test statistic for evaluating mean and covariance structure models under various distributions and sample sizes (Curran, West, \& Finch, 1996; Hu, Bentler, \& Kano, 1992).

Lastly, it is essential to mention that although the researchers had taken care of the procedural remedies to minimize the problems associated with Common Method Bias (CMB) bias (Podsakoff, MacKenzie, \& Podsakoff, 2012), a Confirmatory Factor Analysis (CFA) approach to Harmon's one-factor test (Harman, 1960), known as Common Latent Factor (CLF), was adopted as a statistical remedy to CMB. Based on this type of analysis, the unstandardized factor loadings of the constrained paths were 0.48 , implying that the results were not biased based on $\mathrm{CMB}$ since the square of this value $(23.04 \%)$ was below the threshold of $50 \%$ (Eichhorn, 2014).

\section{RESULTS}

To estimate the 5-factor CFA model, the robust method option in EQS 6.4 model specifications dialogue box was selected, and the factorial structure of the scale developed by Ghasemy et al. (2015) was tested. It is noticeable that the guidelines on handling the issues of non-contributing items set by Hair, Black, Babin, and Anderson (2014) were followed and through this procedure, the items with low factor loadings were eliminated from the model to ensure the fulfilment of the quality criteria with respect to the validity and reliability measures. Through this procedure and after the examination of the items, all the three items of the OOb sub-scale as well as a few other non-contributing items from other sub-scales were eliminated from the hypothesized 5-factor model, causing the 5 -factor model to change into a 4-factor model ${ }^{1}$. In addition, the evaluation of the results of Lagrange Multiplier (LM) test results revealed that two parameters including the error covariances between the items SES_4 and SES_6 and the items SOC_3 and SOC_5 stood apart from the rest and were considered to be freely estimated in a subsequent run.

\section{Validity and Reliability}

As emphasized by Byrne (2016), empirical evidence is required in validating a measurement instrument that the items do measure the construct of interest and in the case of a multidimensional construct, the related sub-scales do exhibit a clear well-defined factor structure consistent with the theory. With respect to the convergent validity, the common measure of Average Variance Extracted (AVE) was computed for each sub-scale. Regarding discriminant validity, another commonly used measure of establishing discriminant validity, known as FornellLarker criterion (Fornell \& Larcker, 1981), was considered. Additionally, we calculated Composite Reliability or CR (Raykov, 1997) for all of the sub-scales.

It is notable that the AVE greater than 0.5 is indicative of convergent validity and the establishment of discriminant validity is confirmed when the square root of AVE of each sub-scale is greater than the correlation of that particular sub-scale with other sub-scales. Furthermore, CR estimate greater than 0.7 is seen as the sign of the fulfilment of CR criterion (Hair et al., 2017).

As displayed in Table 5, all the statistical requirements implying convergent and discriminant validities as well as CR of the multidimensional academic change-oriented leadership capability scale have been achieved. It is noticeable

${ }^{1}$ The items of the final model have been provided in Appendix A. 


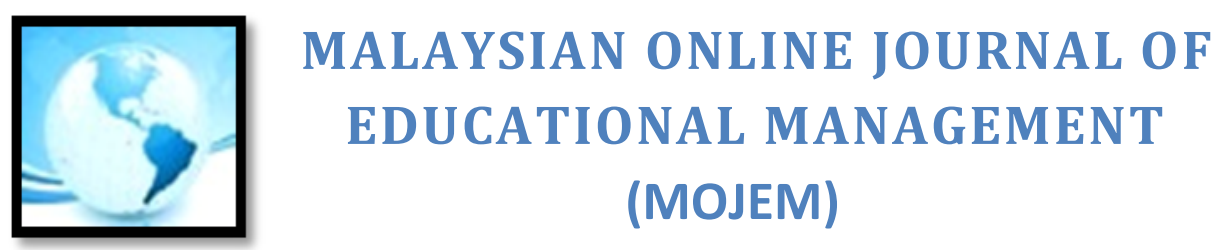

that Maximum Shared Variance (MSV) for each of the factors was smaller than its AVE, indicating the fulfilment of another quality criterion with respect to the discriminant validity (Hair et al., 2014).

Table 5

Reliability and Validity Coefficients

\begin{tabular}{llllllll}
\hline Sub-scale & CR & AVE & MSV & SES & SOC & TOB & HCOF \\
\hline SES & 0.851 & 0.588 & 0.554 & 0.767 & & & \\
SOC & 0.824 & 0.610 & 0.556 & $0.744^{* * *}$ & 0.781 & & \\
TOB & 0.863 & 0.613 & 0.556 & $0.687^{* * *}$ & $0.746^{* * *}$ & 0.783 & 0.782 \\
HCOF & 0.825 & 0.612 & 0.414 & $0.606^{* * *}$ & $0.644^{* * *}$ & $0.642^{* * *}$ & 0.78 \\
\hline
\end{tabular}

$* * *: \mathrm{p}<0.001$

Note: Diagonal elements in bold are the square root of AVE of each sub-scale and the italic off-diagonal elements are the correlations among the sub-scales.

Another great feature of EQS 6.4 is that it can estimate an additional multidimensional reliability coefficient for the tested 4-factor model known as "Reliability Coefficient Rho". As discussed by Byrne (2006), this coefficient is the best choice to report when there are correlated error terms in the model, and the researcher doesn't want such sources of variance to be considered as "True" variance. In this analysis, Rho was estimated to be 0.940, which was promising.

Given the recommendations by Green (2016) and to illustrate the undue impact of multivariate non-normality on standard errors, the researchers have reported the parameter estimates, their standard errors, Critical Ratios (C.R) and their significance values based on the traditional $\mathrm{ML}$ and the robust $\mathrm{ML}$ in Appendix B. Additionally, as suggested by Byrne $(2006,2016)$, all the parameters were examined in terms of their feasibility, appropriateness of standard errors, and their statistical significance. The difference between the standard errors of each parameter can be considered as the effect of multivariate non-normality on estimating the standard errors. The standardized and unstandardized final 4-factor solutions have been shown in Figure 3 and 4. 


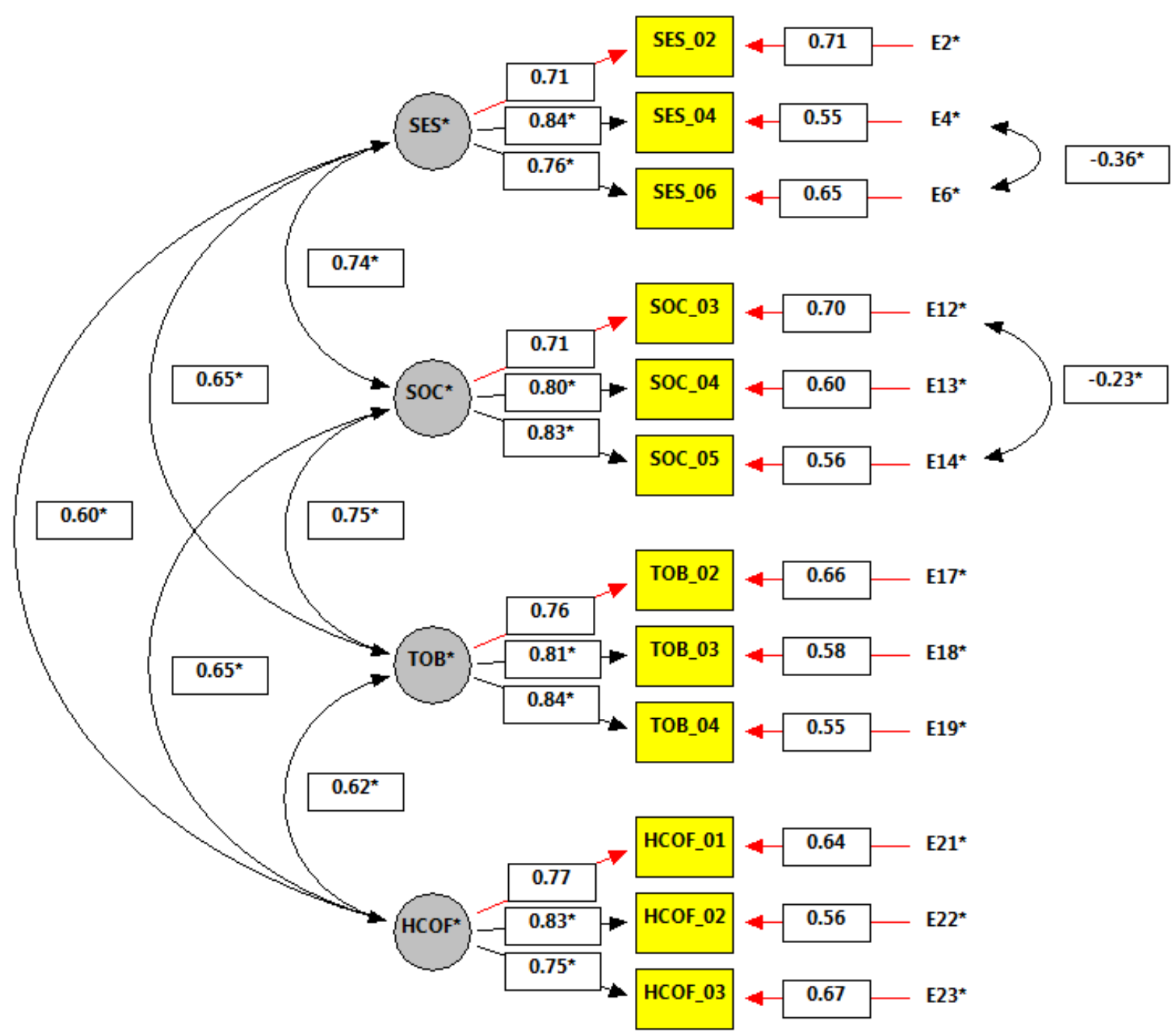

Figure 3. Standardized solution of the 4-factor model of change-oriented leadership capability scale 


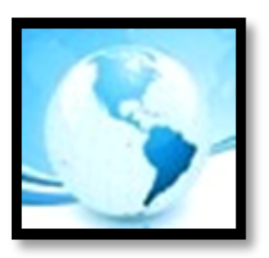

(MOJEM)

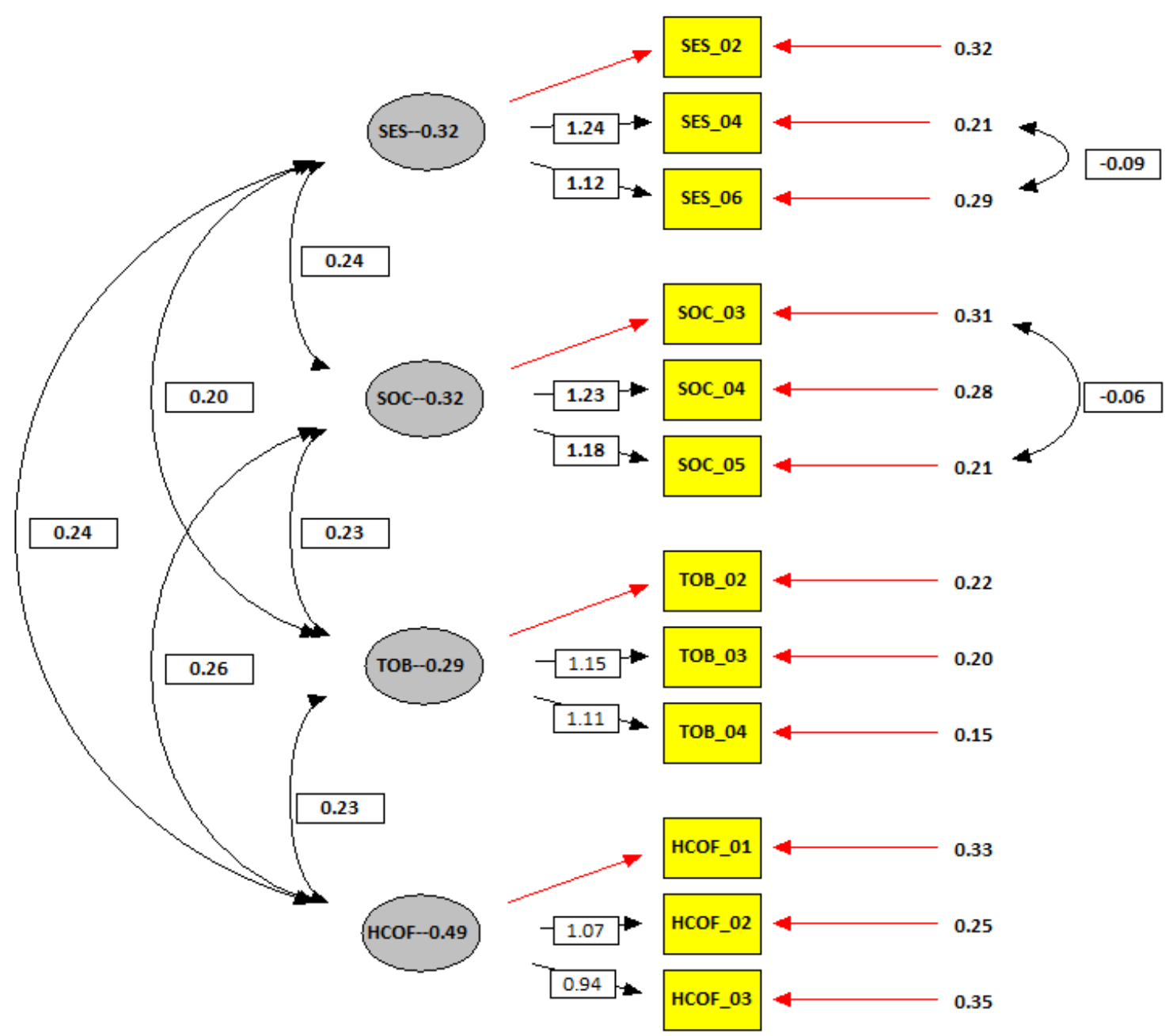

Figure 4. Parameter estimates (unstandardized solution) of the 4-factor model of change-oriented leadership capability

\section{Fit Indices}

Since the robust estimator was selected to correct the chi-square statistic and standard errors of the estimates due to the lack of multivariate normality, EQS 6.4 printed two sets of fit indices based on ML theory and the robust ML method. For the sake of comparison of the performance of the robust method and the traditional ML theory method, as addressed and demonstrated by Byrne (2016), both generated sets of indices have been presented in Table 6. Note that the cut-off criteria for fit indices proposed by $\mathrm{Hu}$ and Bentler (1999) were considered for evaluating the extent to which the 4-factor model fits the data. As displayed in Table 6, all the quality criteria with respect to the model fit have been met, indicating the excellent fit of the model to the data. 


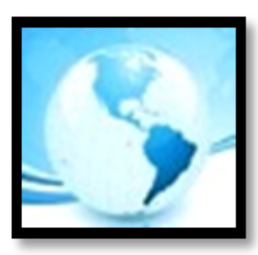

MALAYSIAN ONLINE JOURNAL OF

EDUCATIONAL MANAGEMENT

(MOJEM)

Table 6

Fit Indices Based on ML and Robust ML for the 4-Factor Change-Oriented Leadership Capability Scale

\begin{tabular}{|c|c|c|c|c|}
\hline Fit indexes/ Coefficients & $\begin{array}{l}\text { ML theory } \\
\text { Method }\end{array}$ & $\begin{array}{l}\text { Robust ML } \\
\text { Method* }\end{array}$ & Threshold & Interpretation \\
\hline Chi-Square & 104.149 & $77.8634^{* *}$ & \#\#\#\# & \#\#\#\# \\
\hline DF & 46 & 46 & \#\#\#\# & \#\#\#\# \\
\hline Chi-Square /DF & 2.64 & 1.69 & Between & Excellent fit \\
\hline Bentler-Bonett's Normed Fit Index (NFI) & 0.954 & 0.956 & Close to 0.95 & Excellent fit \\
\hline Bentler-Bonett's Non-Normed Fit Index & 0.962 & 0.973 & Close to 0.95 & Excellent fit \\
\hline Bentler's Comparative Fit Index (CFI) & 0.974 & 0.981 & Close to 0.95 & Excellent fit \\
\hline Bollen's Incremental Fit Index (IFI) & 0.974 & 0.982 & Close to 0.95 & Excellent fit \\
\hline Mcdonald's Fit Index (MFI) & 0.926 & 0.959 & Close to 0.90 & Excellent fit \\
\hline Joreskog-Sorbom's Goodness-Of-Fit Index (GFI) & 0.956 & Not & \#\#\#\# & \#\#\#\# \\
\hline Joreskog-Sorbom's Adjusted Goodness-Of-Fit & 0.925 & Not & \#\#\#\# & \#\#\#\# \\
\hline Root Mean-Square Residual (RMR) & 0.024 & Not & \#\#\#\# & \#\#\#\# \\
\hline Standardized RMR (SRMR) & 0.034 & Not & \#\#\#\# & \#\#\#\# \\
\hline $\begin{array}{l}\text { Root Mean-Square Error of Approximation } \\
90 \% \text { Confidence Interval of RMSEA }\end{array}$ & $\begin{array}{l}0.058 \\
(0.043\end{array}$ & $\begin{array}{l}0.043 \\
(0.026\end{array}$ & $\begin{array}{l}\text { Less than } 0.06 \\
\text { \#\#\#\# }\end{array}$ & $\begin{array}{l}\text { Excellent fit } \\
\text { \#\#\#\# }\end{array}$ \\
\hline
\end{tabular}

$*$ : The indices under robust method are corrected indices

$* *$ : The corrected chi-square known as S-B chi-square

***: Bentler-Bonett's Non-Normed Fit Index and Tucker-Lewis Index (TLI) are identical

As the last attempt to investigate the fit of the model to the data, the standardized residual matrix was focused on. The average absolute standardized residual was 0.022 , and the average off-diagonal absolute standardized residual was 0.026 . Moreover, the review of the frequency distribution of the standardized residuals revealed that $98.72 \%$ of standardized residuals fell between -0.1 and 0.1 . These statistics reflected the fit of the model to the data as well (Byrne, 2006).

\section{DISCUSSION}

In this study, a robust method was applied to test the factorial validity of a previously developed academic changeoriented capability scale. As explained in the previous section, all the statistical assumptions were considered, and the results provided strong empirical evidence for the factorial validity of the 4-factor, rather than 5-factor, model of change-oriented leadership capability scale. This result was consistent with the latest studies on the nature and dimensions of change-oriented capability carried out by Arvonen (2008) and Yukl (2012).

Additionally, fitting the model to the data through a rigorous procedure, it was evident that the items of the validated model through this study were in alignment with the proposed principles of implementing successful change programs (Kotter, 1999) as well as the suggestions to avoid pitfalls in making successful reforms in educational settings (Fullan, 2002). Moreover, while the phenomenon of resistance to change may happen when leaders do not prepare the organization for change through properly envisioning change and communicating this achievable vision throughout the entire organization (Roueche, Baker, \& Rose, 1989), the change-oriented capabilities categorized under "Thinking Out of the Box" sub-scale enable the leaders to significantly overcome this main challenge. More interestingly, a shared understanding of the vision has been deliberated as one of the issues that transformations in universities frame around it (Mader, 2012). Furthermore, the information and knowledge aspect of leadership, which has been addressed by none of the four main approaches to leadership namely, trait, style, contingency and the transformational and charismatic approaches (Lakshman, 2007), has been addressed through the items "Providing information showing how similar work units or competitors have better performance", "Explaining about undesirable outcomes that are likely to occur if new opportunities are exploited 


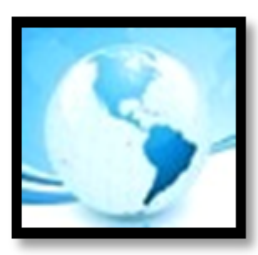

\section{MALAYSIAN ONLINE JOURNAL OF EDUCATIONAL MANAGEMENT (MOJEM)}

by competitors", and "Offering ideas about new and different ways of doing things and accepting innovative proposals".

It is noteworthy that the capabilities introduced through this validation study were consistent with the purposes of HEls (Dearing, 1997). Examples include enabling individuals to enhance their competences and knowledge, forming a democratic, civilized, and inclusive society, and serving the needs of the flexible, sustainable, and knowledgebased economy at different levels. This is an interesting result suggesting that not only universities should be change-capable (Fullan \& Scott, 2009), but also they should be sustainable and foster the concept of sustainability. In fact, since sustainability in universities has been conceptualized on the premises of the four pillars of social, economic, cultural and environmental sustainability introduced by the United Nations, leadership was viewed as one of the pivotal elements toward achieving sustainability in universities in order to create a sustainable future for the society (Scott et al., 2012). It can also be inferred that training academic leaders based on the validated change-oriented leadership capability scale can be an essential step to take to hit this target. It is remarkable to highlight that there is a significant overlap between the 15 leadership qualities required to solve sustainability challenges (Scott et al., 2012) and the 12 items of the validated change-oriented leadership capability scale through our study. This denotes the importance of practicing this type of leadership in institutions of higher learning in the current era of change, growth, and sustainability.

Finally, although the evidence of discriminant validity for the 4-factor model of change-oriented capability was provided in this study, due to the high correlation among these four factors and to avoid collinearity problems among exogenous variables in the structural models (Hair et al., 2017), change-oriented capability has been modelled as a second-order construct as well. This second-order construct has been depicted in Appendix C and D, and the related fit indices have been provided in Appendix $\mathrm{E}$.

\section{CONCLUSION}

This study aimed at validating a multidimensional academic change-oriented capability scale. There were different practical, theoretical, and methodological motivations to conduct this study. Among these reasons and motivations, a few such as the role of change-oriented leadership style in (i) achieving sustainability objectives, (ii) providing a framework of reference for updating academic leadership training and development programs, and (iii) providing the applied researchers and practitioners with a multidimensional scale to conduct research works in the area of implementing change programs in academic contexts deemed to be the main ones. This study's analysis clearly showed that the change-oriented capability scale in academic settings, in concordant with other main studies on conceptualizing and theorizing change-oriented leadership behaviours (Arvonen, 2008; Yukl, 2012), is a 4-factor construct. More specifically, strategic environmental scanning, supporting organizational culture, thinking out of the box, and having clear objective focus were identified as the main components of this type of leadership capability in the context of institutions of higher learning.

From a practical lens, the study has remarkable implications due to its ability to emphasize the issue of sustainable development and to link implementation of change and transformation programs in educational settings with Sustainable Development Goal 4 (SDG 4), which focuses on providing quality education. In fact, adjusting academic leadership development programs based on the validated 4-factor model of change-oriented leadership capability scale seems to be promising as this type of leadership style covers a wider range of capabilities comparing with charismatic and transformation leadership theories (Yukl, 2004). Markedly, as quoted by Fullan and Scott (2009), since identification, selection, and development of leaders in academic settings have not been generally wellmanaged (Aziz et al., 2005; Debowski \& Blake, 2004), leadership selection and training ought to become the new priorities for institutions of higher learning. Hence, the contents of leadership development programs can be updated based on the capabilities constructing change-oriented leadership capability. 


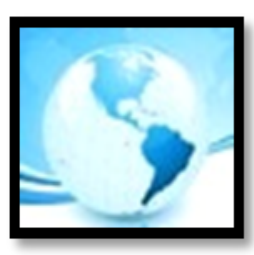

\section{MALAYSIAN ONLINE JOURNAL OF EDUCATIONAL MANAGEMENT (MOJEM)}

With respect to the theoretical perspective, the study expanded the borders of organizational leadership knowledge and theory through confirming the new scale of change-oriented leadership capability (Arvonen, 2008; Ekvall, 1991; Ekvall \& Arvonen, 1991, 1994; Yukl, 2004, 2012, 2013; Yukl et al., 2002) that can be employed in academic settings. Additionally, considering the multicultural, multiracial and multilingual Malaysia with a high rate of diversity and given the fact that many international staff work in public and private universities in this country, the validated scale seems to be a good scale to measure change-oriented leadership in a broader HE system at regional and global levels. Moreover, it suggests that the most effective leadership style, which can be adopted by the university leaders in order to create a sustainable university that can be effective in promoting the society as well as cultivating leaders of the future to deal with the main social, environmental, cultural and economic challenges may be change-oriented leadership.

Regarding the methodological issues, as quoted by Tomarken and Waller (2005), given the examination of the distributional properties of the data prior to fitting the model to the data through SEM is not considered by many researchers (Yuan \& Bentler, 2001) and concordant with the best-practices proposed by Green (2016) with respect to the proper application of the method, the issue of multivariate non-normality was addressed and dealt with through applying the robust ML method (Bryant \& Satorra, 2012; Chou et al., 1991; Satorra \& Bentler, 1988, 1994, $2001,2010)$ available in EQS 6.4 software package. Additionally, the original and the robust chi-square statistics as well as the original and the robust versions of the standard errors were compared as another important methodological implication. Moreover, as encouraged by Yuan and Bentler (2001) and Lee and Xu (2003), prior to fitting the model to the data, the existence of outliers within the data was investigated to avoid any bias in the results of SEM. In fact, given that in educational research, as demonstrated by Schreiber, Nora, Stage, Barlow, and King (2006), the issues with respect to reporting multivariate normality, outliers, predicting and replacing missing values, and standardized residuals analysis have been generally neglected by the researchers, this research work in the context of HE prove considerably meaningful and valuable in terms of the methods and techniques applied.

With respect to limitations, the limited number of vice-chancellors and deputy vice-chancellors compared to the number of other participants of the study, online survey distribution due to the shortage of the budget and inability to travel to different states to collect data, and unavailability of the email addresses of a group of potential respondents in the websites of the universities were the major ones. It is worth noting that the accuracy of the findings was a function of the truthfulness and sincerity of the respondents. Hence, it has been assumed that the respondents were honest in answering the questions and avoided any bias to reflect other irrelevant issues.

Lastly, regarding the recommendations, the researchers invite future researchers to employ our validated scale for data collection in projects related to implementing change programs in academic settings. More study is also needed to determine the utility of the change-oriented leadership capability scale for understanding the influence and importance of any of the four sub-scales in determining leadership performance. Although all the statistical requirements of the analysis were met to ensure the validity and reliability of the scale, it is recommended that additional research studies are indispensable to further evaluate the creditability of the validated academic change-oriented leadership capability scale. Lastly, the standardized and unstandardized solutions as well as the fit indices of the academic change-oriented leadership capability, as a second-order construct, have been presented in the appendix section. Hence, the researchers will be able to model this variable as a second-order construct in their structural equation models too.

\section{ACKNOWLEDGEMENT}

The research team would like to appreciate the editor, the anonymous reviewers and the editorial office staff of Malaysian Online Journal of Educational Management. In addition, a sincere gratitude is extended to EQS support team for the invaluable comments to improve this contribution. 


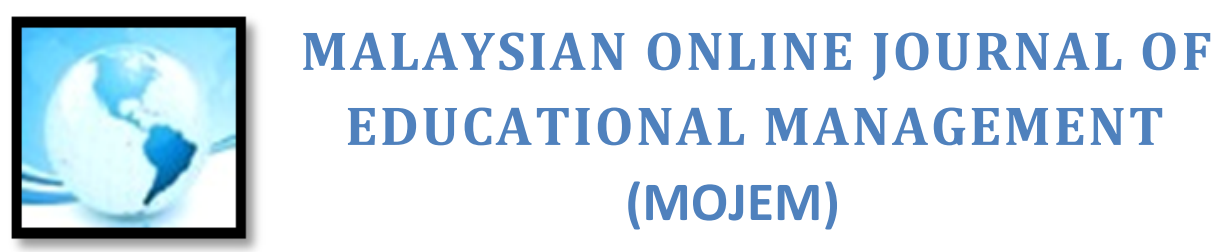

COMPLIANCE WITH ETHICAL STANDARDS

The authors declare that they have no conflict of interest.

\section{FUNDING}

This study has not been funded by any agencies, foundations, or organizations.

\section{DATA AVAILABILITY STATEMENT}

The datafile containing 378 cases used to estimate the model have been published at Harvard Dataverse and is available at https://doi.org/10.7910/DVN/KK9LUD.

\section{ETHICAL ISSUES}

All procedures performed in studies involving human participants were in accordance with the ethical standards of the institutional research committee of the lead author and with the 1964 Helsinki declaration and its later amendments or comparable ethical standards.

\section{REFERENCES}

Arvonen, J. (2008). Change-oriented leadership behaviour: A consequence of post-bureauratic organisations? In T. Rickards, M. A. Runco, \& S. Moger (Eds.), The Routledge Companion to Creativity (pp. 302-313). London: Routledge.

Avolio, B. J., \& Gibbons, T. C. (1988). Developing transformational leaders: A life span approach. In Charismatic leadership: The elusive factor in organizational effectiveness (pp. 276-307). San Fransisco: Jossey-Bass.

Aziz, S., Mullins, M. E., Balzer, W. K., Grauer, E., Burnfield, J. L., Lodato, M. A., \& Cohen-Powless, M. A. (2005). Understanding the training needs of department chairs. Studies in Higher Education, 30(5), 571-593. doi:10.1080/03075070500249260

Bass, B. M. (1960). Leadership, psychology, and organizational behaviour. New York: Harper.

Bass, B. M., \& Stogdill, R. M. (1990). Bass \& Stogdill's handbook of leadership: Theory, research, and managerial applications (3rd ed.). New York: Free Press.

Bentler, P. M. (1985). Theory and implementation of EQS: A structural equations program. Los Angeles: BMDP Statistical Software.

Bentler, P. M. (2006). EQS 6 structural equations program manual. Encino, CA: Multivariate Software, Inc.

Black, S. A. (2015). Qualities of effective leadership in higher education. Open Journal of Leadership, 4(2), 54-66. doi:10.4236/ojl.2015.42006

Blake, R. R., \& Mouton, J. S. (1985). The managerial grid III: A new look at the classic that has boosted productivity and profits for thousands of corporations worldwide ( $3^{\text {rd }}$ ed.). Houston: Gulf Publishing Company.

Borgmann, L., Rowold, J., \& Bormann, K. C. (2016). Integrating leadership research: a meta-analytical test of Yukl's meta-categories of leadership. Personnel Review, 45(6), 1340-1366. doi:10.1108/PR-07-2014-0145

Bryant, F. B., \& Satorra, A. (2012). Principles and practice of scaled difference Chi-Square Testing. Structural Equation Modeling: A Multidisciplinary Journal, 19(3), 372-398. doi:10.1080/10705511.2012.687671

Byrne, B. M. (2006). Structural equation modeling with EQS: Basic concepts, applications, and programming (2 ${ }^{\text {nd }}$ ed.). London: Lawrence Erlbaum Associates

Byrne, B. M. (2016). Structural equation modeling with AMOS: Basic concepts, applications, and programming (3 ed.). New York: Routledge.

Chou, C.-p., Bentler, P. M., \& Satorra, A. (1991). Scaled test statistics and robust standard errors for non-normal data in covariance structure analysis: A Monte Carlo study. British Journal of Mathematical and Statistical 


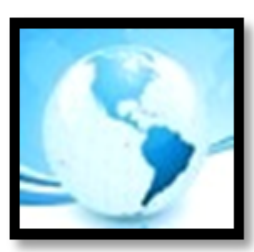

MALAYSIAN ONLINE JOURNAL OF

EDUCATIONAL MANAGEMENT

(MOJEM)

Psychology, 44(2), 347-357. doi:10.1111/j.2044-8317.1991.tb00966.x

Creswell, J. W. (2012). Educational research: Planning, conducting, and evaluating quantitative and qualitative research ( $4^{\text {th }}$ ed.). Boston: Pearson Education, Inc.

Croucher, G., \& Lacy, W. B. (2020). Perspectives of Australian higher education leadership: convergent or divergent views and implications for the future? Journal of Higher Education Policy and Management, 1-14.

Curran, P. J., West, S. G., \& Finch, J. F. (1996). The robustness of test statistics to nonnormality and specification error in confirmatory factor analysis. Psychological methods, 1(1), 16-29.

Dearing, R. (1997). Higher education in the learning society. London: HMSO.

Debowski, S., \& Blake, V. (2004, 9-10 February). The developmental needs of higher education academic leaders in encouraging effective teaching and learning. Paper presented at the 13th Annual Teaching Learning Forum, Perth.

DeCarlo, L. T. (1997). On the meaning and use of kurtosis. Psychological Methods, 2(3), 292-307.

Eichhorn, B. R. (2014). Common method variance techniques. Paper presented the MWSUG 2014, Chicago, Illinois.

Ekvall, G. (1991). Change-centred leaders: Empirical evidence of a third dimension of leadership. The Leadership \& Organization Development Journal, 12(6), 18-23. doi:10.1108/EUM0000000001162

Ekvall, G., \& Arvonen, J. (1991). Change-centered leadership: An extension of the two-dimensional model. Scandinavian Journal of Management, 7(1), 17-26. doi:10.1016/0956-5221(91)90024-U

Ekvall, G., \& Arvonen, J. (1994). Leadership profiles, situation and effectiveness. Creativity and Innovation Management, 3(3), 139-161. doi:10.1111/j.1467-8691.1994.tb00168.x

Ekvall, G., \& Ryhammar, L. (1998). Leadership style, social climate and organizational outcomes: A study of a Swedish University College. Creativity and Innovation Management, 7(3), 126-130. doi:10.1111/14678691.00100

Finney, S. J., \& DiStefano, C. (2006). Non-normal and categorical data in structural equation modeling. In G. R. Hancock \& R. O. Mueller (Eds.), Structural equation modeling: A second course (pp. 269-314). Greenwich, CT: Information Age Publishing.

Fleishman, E. A., \& Harris, E. F. (1962). Patterns of leadership behaviour related to employee grievances and turnover. Personnel Psychology, 15(1), 43-56. doi:10.1111/j.1744-6570.1962.tb01845.x

Fornell, C., \& Larcker, D. F. (1981). Evaluating structural equation models with unobservable variables and measurement error. Journal of marketing research, 18(1), 39-50. doi:10.2307/3151312

Fullan, M. G. (2002). The change leader. Educational leadership, 59(8), 16-21.

Fullan, M. G., \& Scott, G. (2009). Turnaround leadership for higher education. San Francisco: Jossey-Bass.

Ghasemy, M. (2017). Capabilities and competencies related to leadership performance effectiveness in the context of change in Malaysian higher education institutions (Unpublished Doctoral Dissertation). University of Malaya, Malaysia. Retrieved from http://studentsrepo.um.edu.my/id/eprint/7508

Ghasemy, M., Sufean, H., Ahmad Zabidi, A. R., Mohd Jamil, M., \& Ghavifekr, S. (2018). Determining the key capacities of effective leaders in Malaysian public and private focused universities. SAGE Open, 8(4), 1-12. doi:10.1177/2158244018807620

Ghasemy, M., Sufean, H., \& Megat Ahmad Kamaluddin, M. D. (2015, 16-18 November). The Malaysian version of change-oriented leadership behaviours scale in academic settings: A quality scale development using Velicer's MAP test with a small sample size. Paper presented at the iCERi2015, Seville, Spain.

Ghasemy, M., Sufean, H., \& Megat Ahmad Kamaluddin, M. D. (2017). The key determinants of leadership performance effectiveness in public research and comprehensive universities: An advanced PLS-SEM study in Malaysian context. Malaysian Online Journal of Educational Management, 5(1), 62-81. doi:10.22452/mojem.vol5no1.5

Ghasemy, M., Sufean, H., Megat Ahmad Kamaluddin, M. D., Ahmad Zabidi, A. R., \& Mohd Jamil, M. (2017). Pivotal qualities for effective university leadership on the basis of a modified Australian model: the application of FIMIX-PLS and IPMA in the Malaysian academic context. Asia Pacific Education Review, 18(4), 501-517. doi:10.1007/s12564-017-9504-7

Ghasemy, M., Sufean, H., Megat Ahmad Kamaluddin, M. D., Mariani, M. N., Ghavifekr, S., \& Husaina Banu, K. 


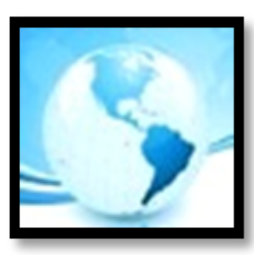

\section{MALAYSIAN ONLINE JOURNAL OF EDUCATIONAL MANAGEMENT (MOJEM)}

(2018). Issues in Malaysian higher education: A quantitative representation of the top five priorities, values, challenges, and solutions from the viewpoints of academic leaders. SAGE Open, 8(1), 1-15. doi:10.1177/2158244018755839

Gil, F., Rico, R., Alcover, C. M., \& Barrasa, A. (2005). Change-oriented leadership, satisfaction and performance in work groups: Effects of team climate and group potency. Journal of Managerial Psychology, 20(3/4), 312328. doi:10.1108/02683940510589073

Golm, H. (2009). Examining the relationship between transformational, transactional, and change-oriented leadership and their influence on leadership effectiveness. (Unpublished Doctoral Dissertation). Columbia University, USA. (No. 3373742)

Green, T. (2016). A methodological review of structural equation modelling in higher education research. Studies in Higher Education, 41(12), 2125-2155.

Hair, J. F., Black, W. C., Babin, B. J., \& Anderson, R. E. (2014). Multivariate data analysis: Pearson new international edition ( $7^{\text {th }}$ Ed.). Harlow: Pearson Education Limited.

Hair, J. F., Hult, G. T. M., Ringle, C. M., \& Sarstedt, M. (2017). A primer on Partial Least Squares Structural Equation Modeling (PLS-SEM) (2 ${ }^{\text {nd }}$ Ed.). Thousand Oaks, CA: Sage.

Hansson, P. H., \& Andersen, J. A. (2007). The Swedish principal: Leadership style, decision-making style, and motivation profile. International Electronic Journal for Leadership in Learning, 14(1), 47-60.

Harman, H. H. (1960). Modern factor analysis. Chicago, IL: University of Chicago Press.

Hersey, P., \& Blanchard, K. H. (1988). Management of organizational behaviour: Utilizing human resources (5 ${ }^{\text {th }}$ Ed.). Englewood Cliffs, NJ: Prentice-Hall.

Ho, R. (2013). Handbook of univariate and multivariate data analysis with IBM SPSS (2 ed.). Boca Raton, Florida: CRC Press.

Holloway, J. B. (2013). Employee job satisfaction, psychological state, and change-oriented leadership behaviour in community behavioral health organizations (Unpublished Doctoral Dissertation). Regent University, London. (No. 3578591)

Hu, L.-t., \& Bentler, P. M. (1999). Cutoff criteria for fit indexes in covariance structure analysis: Conventional criteria versus new alternatives. Structural Equation Modeling: A Multidisciplinary Journal, 6(1), 1-55. doi:10.1080/10705519909540118

Hu, L.-t., Bentler, P. M., \& Kano, Y. (1992). Can test statistics in covariance structure analysis be trusted? Psychological Bulletin, 112(2), 351-362.

Khalili, A. (2017). Creative and innovative leadership: Measurement development and validation. Management Research Review, 40(10), 1117-1138. doi:10.1108/MRR-09-2016-0213

King, G. Jr. (2017). A comparison between administrative leadership in higher education and change-oriented leadership in banks (Unpublished Doctoral Dissertation). Walden University, Minneapolis, Minnesota.

Kotter, J. P. (1999). Change leadership. Executive Excellence, 16(4), 16-17.

Lakshman, C. (2007). Organizational knowledge leadership: A grounded theory approach. The Leadership \& Organization Development Journal, 28(1), 51-75. doi:10.1108/01437730710718245

Lee, S.-Y., \& Xu, L. (2003). Case-deletion diagnostics for factor analysis models with continuous and ordinal categorical data. Sociological methods \& research, 31(3), 389-419. doi:10.1177/0049124102239081

Lewin, K. (1950). The consequences of an authoritarian and democratic leadership. In G. A. W (Ed.), Studies in leadership (pp. 409-417). New York: Harper \& Row.

Likert, R. (1961). New patterns of management. New York: McGraw-Hill.

Mader, C. (2012). How to assess transformative performance towards sustainable development in higher education institutions. Journal of Education for Sustainable Development, 6(1), 79-89. doi:10.1177/097340821100600114

Malm, J. R. (2008). Six community college presidents: Organizational rressures, change processes and approaches to leadership. Community College Journal of Research and Practice, 32(8), 614-628. doi:10.1080/10668920802103813

Mardia, K. V. (1970). Measures of multivariate skewness and kurtosis with applications. Biometrika, 57(3), 519-530. doi:10.1093/biomet/57.3.519 


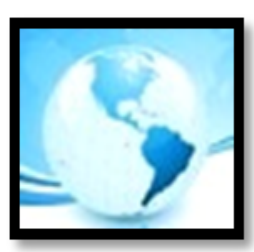

MALAYSIAN ONLINE JOURNAL OF

EDUCATIONAL MANAGEMENT

(MOJEM)

Mardia, K. V. (1974). Applications of some measures of multivariate skewness and kurtosis in testing normality and robustness studies. Sankhyā: The Indian Journal of Statistics, Series B (1960-2002), 36(2), 115-128.

Marinova, S. V., Peng, C., Lorinkova, N., Van Dyne, L., \& Chiaburu, D. (2015). Change-oriented behaviour: A metaanalysis of individual and job design predictors. Journal of vocational behaviour, 88(1), 104-120. doi:10.1016/j.jvb.2015.02.006

Mourad, M. (2013). Students' perception of quality assurance activities: Case study from the European higher education market. Sustainability Accounting, Management and Policy Journal, 4(3), 345-365. doi:10.1108/SAMPJ-01-2013-0007

O'Connor, B. P. (2000). SPSS and SAS programs for determining the number of components using parallel analysis and Velicer's MAP test. Behavior research methods, instruments, \& computers, 32(3), 396-402. doi:10.3758/BF03200807

Ortega, A., Van den Bossche, P., Sánchez-Manzanares, M., Rico, R., \& Gil, F. (2013). The Influence of changeoriented leadership and psychological safety on team learning in healthcare teams. Journal of Business and Psychology, 29(2), 311-321. doi:10.1007/s10869-013-9315-8

Podsakoff, P. M., MacKenzie, S. B., \& Podsakoff, N. P. (2012). Sources of method bias in social science research and recommendations on how to control it. Annual review of psychology, 63(1), 539-569. doi:10.1146/annurev-psych-120710-100452

Raykov, T. (1997). Estimation of composite reliability for congeneric measures. Applied Psychological Measurement, 21(2), 173-184. doi:10.1177/01466216970212006

Roueche, J. E., Baker, G. A., \& Rose, R. R. (1989). Shared vision: Transformational leadership in American community colleges. Washigton, DC: National Center for Higher Education.

Satorra, A., \& Bentler, P. M. (1988). Scaling corrections for chi-square statistics in covariance structure analysis. Paper presented at the Proceedings of the American Statistical Association, Business and Economic Statistics Section, Washington, DC.

Satorra, A., \& Bentler, P. M. (1994). Corrections to test statistics and standard errors in covariance structure analysis. In A. V. Eye \& C. C. Clogg (Eds.), Latent variable analysis: Application for development research (pp. 399-419). Thousand Oaks, CA: Sage.

Satorra, A., \& Bentler, P. M. (2001). A scaled difference chi-square test statistic for moment structure analysis. Psychometrika, 66(4), 507-514. doi:10.1007/bf02296192

Satorra, A., \& Bentler, P. M. (2010). Ensuring positiveness of the scaled difference chi-square test statistic. Psychometrika, 75(2), 243-248. doi:10.1007/s11336-009-9135-y

Schreiber, J. B., Nora, A., Stage, F. K., Barlow, E. A., \& King, J. (2006). Reporting structural equation modeling and confirmatory factor analysis results: A review. The Journal of Educational Research, 99(6), 323-338. doi:10.3200/JOER.99.6.323-338

Scott, G., Tilbury, D., Sharp, L., \& Deane, E. (2012). Turnaround leadership for sustainability in higher education. Sydney: Office of Learning and Teaching, Australian Government.

Sellgren, S. F., Ekvall, G., \& Tomson, G. (2008). Leadership behaviour of nurse managers in relation to job satisfaction and work climate. Journal of Nursing Management, 16(5), 578-587. doi:10.1111/j.13652934.2007.00837.x

Sirén, C., Patel, P. C., \& Wincent, J. (2016). How do harmonious passion and obsessive passion moderate the influence of a CEO's change-oriented leadership on company performance? The Leadership Quarterly, 27(4), 653-670. doi:10.1016/j.leaqua.2016.03.002

Stensaker, B., Frølich, N., Huisman, J., Waagene, E., Scordato, L., \& Bótas, P. P. (2014). Factors affecting strategic change in higher education. Journal of Strategy and Management.

Tannenbaum, R., \& Schmidt, W. H. (1973). How to choose a leadership pattern. Harvard Business Review, 51, 162180.

Tomarken, A. J., \& Waller, N. G. (2005). Structural equation modeling: Strengths, limitations, and misconceptions. Annual Review of Clinical Psychology, 1(1), 31-65. doi:10.1146/annurev.clinpsy.1.102803.144239

Vardaman, D. L. (2013). Leading change: Exploring the relationship between transformational, transactional, and change-oriented leadership and their impact on leadership effectiveness among pastors in a protestant 


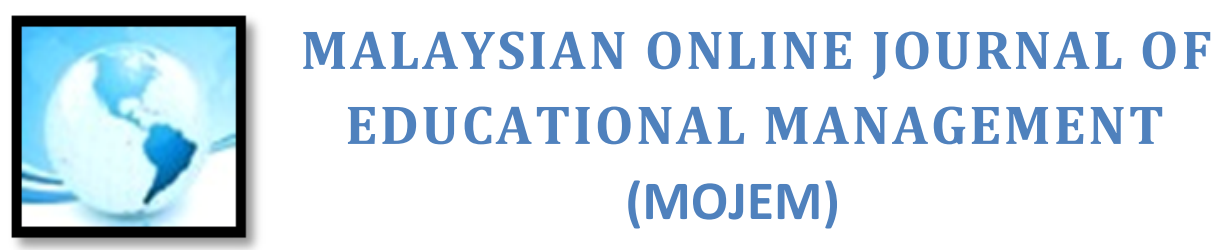

denomination in the mid-western United States (Unpublished Doctoral Dissertation). Indiana Wesleyan University, (3613541)

West, S. G., Finch, J. F., \& Curran, P. J. (1995). Structural equation models with non-normal variables: Problems and remedies. In R. H. Hoyle (Ed.), Structural equation modeling: Concepts, issues and applications (pp. 56-75). Thousand Oaks, CA: Sage.

Yuan, K. H., \& Bentler, P. M. (2001). Effect of outliers on estimators and tests in covariance structure analysis. British Journal of Mathematical and Statistical Psychology, 54(1), 161-175. doi:10.1348/000711001159366

Yukl, G. (1999). An evaluative essay on current conceptions of effective leadership. European Journal of Work and Organizational Psychology, 8(1), 33-48. doi:10.1080/135943299398429

Yukl, G. (2004). Tridimensional leadership theory: A roadmap for flexible, adaptive leaders. In R. J. Burke \& C. Cooper (Eds.), Leading in turbulent times: Managing in the new world of work (pp. 75-91). London: Wiley.

Yukl, G. (2012). Effective leadership behaviours: What we know and what questions need more attention? The Academy of Management Perspectives, 26(4), 66-85. doi:10.5465/amp.2012.0088

Yukl, G. (2013). Leadership in organizations (8th Ed.). Boston, MA: Pearson.

Yukl, G., Gordon, A., \& Taber, T. (2002). A hierarchical taxonomy of leadership behaviour: Integrating a half century of behaviour research. Journal of Leadership \& Organizational Studies, 9(1), $15-32$. doi:10.1177/107179190200900102

\section{APPENDICES}

Appendix A

Items of the Validated Change-Oriented Leadership Capability Scale in the Context of HE

\begin{tabular}{l|l|l}
\hline Subscale & $\begin{array}{l}\text { Item } \\
\text { Code }\end{array}$ & Item \\
\hline $\begin{array}{l}\text { Strategic } \\
\text { Environmental } \\
\text { Scanning }\end{array}$ & SES_02 & $\begin{array}{l}\text { Monitoring the external environment more when the university is highly dependent } \\
\text { on outsiders, faces severe competition and the environment is rapidly changing } \\
\text { Explaining about undesirable outcomes that are likely to occur if new opportunities } \\
\text { are exploited by competitors } \\
\text { Identifying environmental threats and opportunities for the university and } \\
\text { interpreting the collected information }\end{array}$ \\
\hline $\begin{array}{l}\text { Supporting } \\
\text { Organizational } \\
\text { Culture }\end{array}$ & SES_03 & $\begin{array}{l}\text { Creating an organizational culture that values creativity and entrepreneurial } \\
\text { activities } \\
\text { Providing information showing how similar work units or competitors have better } \\
\text { performance } \\
\text { Providing resources for the people to increase learning from mistakes and failures }\end{array}$ \\
\hline $\begin{array}{l}\text { Thinking Out } \\
\text { of the Box }\end{array}$ & SOB_02 & $\begin{array}{l}\text { Offering ideas about new and different ways of doing things and accepting } \\
\text { innovative proposals } \\
\text { Seeing possibilities rather than problems } \\
\text { Liking and encouraging to discuss new ideas }\end{array}$ \\
\hline $\begin{array}{l}\text { Having Clear } \\
\text { Fobjective }\end{array}$ & $\begin{array}{l}\text { HOB_03 } \\
\text { HCOF_02 } \\
\text { HOCF_03 }\end{array}$ & $\begin{array}{l}\text { Avoiding taking actions that can divert attention from innovative solutions } \\
\text { Avoiding the development of visions based on false assumptions } \\
\text { Avoiding pursuing a risky and unrealistic vision that can result to performance } \\
\text { decline }\end{array}$ \\
\hline
\end{tabular}




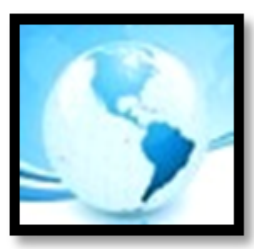

MALAYSIAN ONLINE JOURNAL OF

EDUCATIONAL MANAGEMENT

(MOJEM)

Appendix B

Parameter Estimates Based on the Final Model and Related Statistics

\begin{tabular}{|c|c|c|c|c|c|c|c|c|c|c|c|}
\hline \multirow{2}{*}{\multicolumn{3}{|c|}{$\begin{array}{c}\text { Parameter } \\
\text { (Factor loadings, } \\
\text { covariances, factor } \\
\text { variances, and error } \\
\text { variances) }\end{array}$}} & \multicolumn{4}{|c|}{ ML Method } & \multicolumn{4}{|c|}{ Robust Method } & \multirow{2}{*}{$\begin{array}{l}\text { Standard } \\
\text { Error } \\
\text { Difference }\end{array}$} \\
\hline & & & \multirow{2}{*}{$\begin{array}{c}\text { Estimate } \\
1.000\end{array}$} & \multirow{2}{*}{ 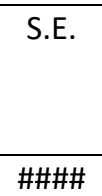 } & \multirow{2}{*}{$\begin{array}{l}\text { C.R. } \\
\\
\# \# \#\end{array}$} & \multirow[t]{2}{*}{ 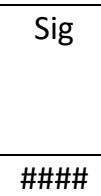 } & \multirow{2}{*}{$\begin{array}{c}\text { Estimate } \\
1.000\end{array}$} & \multirow{2}{*}{ 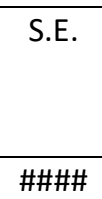 } & \multirow{2}{*}{ 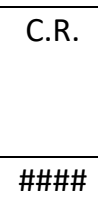 } & \multirow[t]{2}{*}{ 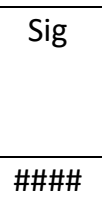 } & \\
\hline SES_02 & $<---$ & SES & & & & & & & & & \#\#\#\# \\
\hline SES_04 & $<---$ & SES & 1.240 & 0.100 & 12.19 & $<0.05$ & 1.240 & 0.112 & 11.09 & $<0.05$ & -0.010 \\
\hline SES_06 & $<---$ & SES & 1.124 & 0.100 & 11.28 & $<0.05$ & 1.124 & 0.112 & 10.06 & $<0.05$ & -0.012 \\
\hline SOC_03 & $<---$ & SOC & 1.000 & \#\#\#\# & \#\#\#\# & \#\#\#\# & 1.000 & \#\#\#\# & \#\#\#\# & \#\#\#\# & \#\#\#\# \\
\hline SOC_04 & $<---$ & SOC & 1.230 & 0.090 & 13.06 & $<0.05$ & 1.230 & 0.093 & 13.17 & $<0.05$ & 0.001 \\
\hline SOC_05 & $<---$ & SOC & 1.178 & 0.090 & 12.94 & $<0.05$ & 1.178 & 0.094 & 12.5 & $<0.05$ & -0.003 \\
\hline TOB_02 & $<---$ & TOB & 1.000 & \#\#\#\# & \#\#\#\# & \#\#\#\# & 1.000 & \#\#\#\# & \#\#\#\# & \#\#\#\# & \#\#\#\# \\
\hline TOB_03 & $<---$ & TOB & 1.155 & 0.080 & 15.30 & $<0.05$ & 1.155 & 0.093 & 12.45 & $<0.05$ & -0.018 \\
\hline TOB_04 & $<---$ & TOB & 1.106 & 0.070 & 15.63 & $<0.05$ & 1.106 & 0.084 & 13.24 & $<0.05$ & -0.013 \\
\hline HCOF_01 & $<--$ & HCOF & 1.000 & \#\#\#\# & \#\#\#\# & \#\#\#\# & 1.000 & \#\#\#\# & \#\#\#\# & \#\#\#\# & \#\#\#\# \\
\hline HCOF_02 & $<---$ & HCOF & 1.069 & 0.070 & 14.96 & $<0.05$ & 1.069 & 0.074 & 14.44 & $<0.05$ & -0.003 \\
\hline HCOF_03 & $<--$ & $\mathrm{HCOF}$ & 0.944 & 0.070 & 13.81 & $<0.05$ & 0.944 & 0.072 & 13.18 & $<0.05$ & -0.004 \\
\hline SES & $<-->$ & SOC & 0.24 & 0.030 & 7.89 & $<0.05$ & & & 8.68 & $<0.05$ & \\
\hline SES & $<-->$ & TOB & 0.2 & 0.030 & 7.64 & $<0.05$ & 0.2 & 0.024 & 8.20 & $<0.05$ & 0.002 \\
\hline SES & $<-->$ & HCOF & 0.238 & 0.030 & 7.29 & $<0.05$ & 0.238 & 0.032 & 7.47 & $<0.05$ & 0.001 \\
\hline SOC & $<-->$ & ТОВ & 0.229 & 0.030 & 8.50 & $<0.05$ & 0.2 & 0 . & 8.65 & $<0.05$ & 0.001 \\
\hline SOC & $<-->$ & $\mathrm{HCOF}$ & 0.256 & 0.030 & 7.85 & $<0.05$ & 0.256 & 0.034 & 7.52 & $<0.05$ & -0.001 \\
\hline ТОВ & $<-->$ & $\mathrm{HCOF}$ & 0.233 & 0.030 & 7.87 & $<0.05$ & 0.2 & 0.028 & 8.31 & $<0.05$ & 0.002 \\
\hline E4 & $<-->$ & E6 & -0.089 & 0.030 & -3.11 & $<0.05$ & -0.089 & 0.032 & -2.78 & $<0.05$ & -0.003 \\
\hline $\mathrm{E} 12$ & $<-->$ & E14 & -0.059 & 0.020 & -2.87 & $<0.05$ & -0.059 & 0.022 & -2.69 & $<0.05$ & -0.001 \\
\hline \multicolumn{3}{|c|}{ SES } & 0.324 & 0.050 & 7.26 & $<0.05$ & 0.324 & 0.048 & 6.80 & $<0.05$ & -0.003 \\
\hline \multicolumn{3}{|c|}{ SOC } & 0.322 & 0.050 & 7.17 & $<0.05$ & 0.322 & 0.046 & 7.03 & $<0.05$ & -0.001 \\
\hline \multicolumn{3}{|c|}{ TOB } & 0.289 & 0.040 & 8.16 & $<0.05$ & 0.289 & 0.038 & 7.64 & $<0.05$ & -0.003 \\
\hline \multicolumn{3}{|c|}{$\mathrm{HCOF}$} & 0.487 & 0.060 & 8.22 & $<0.05$ & 0.487 & 0.068 & 7.18 & $<0.05$ & -0.009 \\
\hline \multicolumn{3}{|c|}{ E2 } & 0.323 & 0.030 & 10.90 & $<0.05$ & 0.323 & 0.035 & 9.20 & $<0.05$ & -0.005 \\
\hline \multicolumn{3}{|c|}{ E4 } & 0.213 & 0.040 & 5.87 & $<0.05$ & 0.213 & 0.042 & 5.05 & $<0.05$ & -0.006 \\
\hline \multicolumn{3}{|c|}{ E6 } & 0.294 & 0.040 & 7.80 & $<0.05$ & 0.294 & 0.045 & 6.55 & $<0.05$ & -0.007 \\
\hline \multicolumn{3}{|c|}{ E12 } & 0.314 & 0.030 & 10.39 & $<0.05$ & 0.314 & 0.041 & 7.60 & $<0.05$ & -0.011 \\
\hline \multicolumn{3}{|c|}{ E13 } & 0.279 & 0.030 & 9.93 & $<0.05$ & 0.279 & 0.040 & 7.01 & $<0.05$ & -0.012 \\
\hline \multicolumn{3}{|c|}{ E14 } & 0.208 & 0.030 & 7.99 & $<0.05$ & 0.208 & 0.027 & 7.27 & $<0.05$ & -0.001 \\
\hline \multicolumn{3}{|c|}{ E17 } & 0.218 & 0.020 & 10.96 & $<0.05$ & 0.218 & 0.049 & 4.45 & $<0.05$ & -0.029 \\
\hline \multicolumn{3}{|c|}{ E18 } & 0.196 & 0.020 & 9.56 & $<0.05$ & 0.196 & 0.036 & 5.48 & $<0.05$ & -0.015 \\
\hline & E19 & & 0.152 & 0.020 & 8.82 & $<0.05$ & 0.152 & 0.020 & 7.79 & $<0.05$ & -0.003 \\
\hline & E21 & & 0.333 & 0.030 & 9.95 & $<0.05$ & 0.333 & 0.054 & 6.17 & $<0.05$ & -0.021 \\
\hline & E22 & & 0.253 & 0.030 & 8.12 & $<0.05$ & 0.253 & 0.046 & 5.49 & $<0.05$ & -0.015 \\
\hline & E23 & & 0.348 & 0.030 & 10.55 & $<0.05$ & 0.348 & 0.051 & 6.80 & $<0.05$ & -0.018 \\
\hline
\end{tabular}

Note: Due to the multivariate non-normality, the results of robust method (S.E. and C.R) must be considered. 


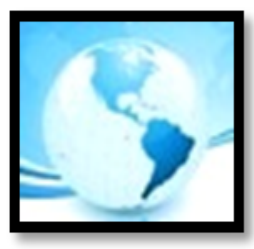

MALAYSIAN ONLINE JOURNAL OF EDUCATIONAL MANAGEMENT

(MOJEM)

Appendix C

Standardized Solution of Change-Oriented Leadership Capability Scale as A Second

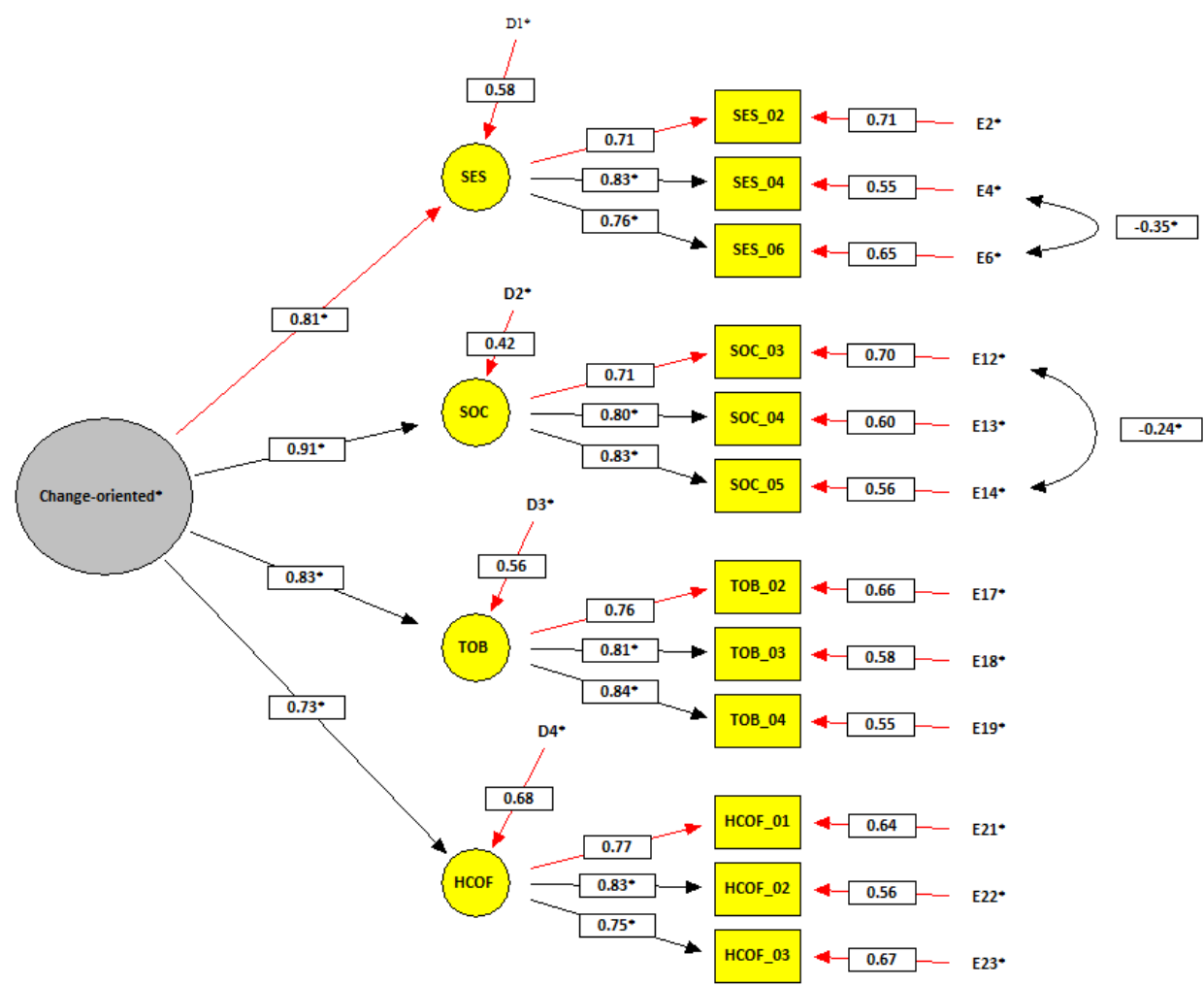




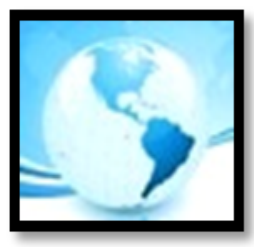

\section{MALAYSIAN ONLINE JOURNAL OF EDUCATIONAL MANAGEMENT \\ (MOJEM)}

Appendix D

Parameter Estimates (Unstandardized Solution) of Change-Oriented Leadership Capability Scale as A Second-Order Construct

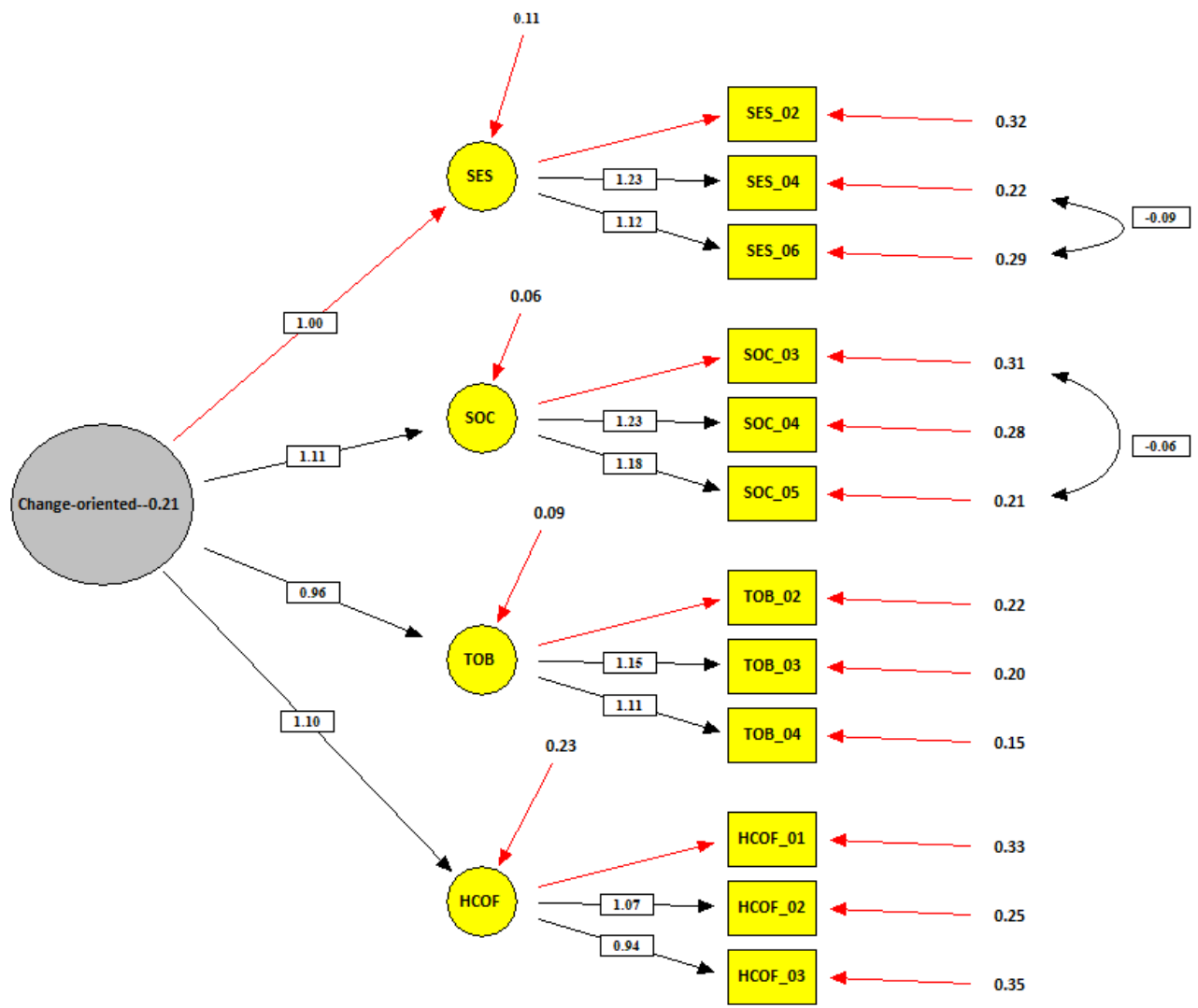




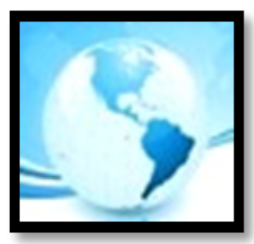

MALAYSIAN ONLINE JOURNAL OF

EDUCATIONAL MANAGEMENT

(MOJEM)

Appendix $\mathrm{E}$

Fit Indexes Based on ML and Robust ML for the Second Order Scale of Change-Oriented Leadership Capability with Four Factors

\begin{tabular}{|c|c|c|c|c|}
\hline Fit indexes/ Coefficients & ML theory Method & Robust ML & Threshold & Interpretation \\
\hline CHI-SQUARE & 105.574 & $77.825^{* *}$ & \#\#\#\# & \#\#\#\# \\
\hline DF & 48 & 48 & \#\#\#\# & \#\#\#\# \\
\hline CHI-SQUARE /DF & 2.20 & 1.62 & Between 1 & Excellent fit \\
\hline $\mathrm{NFI}$ & 0.954 & 0.956 & Greater & Excellent fit \\
\hline NNFI (or TLI) & 0.964 & 0.976 & Greater & Excellent fit \\
\hline $\mathrm{CFI}$ & 0.974 & 0.983 & Greater & Excellent fit \\
\hline IFI & 0.974 & 0.983 & Greater & Excellent fit \\
\hline MFI & 0.927 & 0.961 & Greater & Excellent fit \\
\hline RMSEA & 0.056 & 0.041 & Less than & Excellent fit \\
\hline 90\% CONFIDENCE INTERVAL OF & $(0.042,0.071)$ & $(0.023,0.057)$ & \#\#\#\# & \#\#\#\# \\
\hline
\end{tabular}

*: The indices under robust method are corrected indices

**: The corrected chi-square known as S-B chi-square 